\title{
Picosecond Laser Modification of CIGS Active Layer
}

\author{
Paulius Gečys, Edgaras Markauskas, Andrius Žemaitis and Gediminas Račiukaitis \\ Center for Physical Sciences and Technology, Savanoriu Ave. 231, LT-02300, Vilnius, Lithuania \\ E-mail: p.gecys@ftmc.lt
}

\begin{abstract}
$\mathrm{Cu}$-chalcopyrite based solar cells such as $\mathrm{Cu}(\mathrm{In}, \mathrm{Ga}) \mathrm{Se}_{2}$ (CIGS) have been established as the most efficient thin-film technology in converting sunlight into electricity. Laser scribed monolithic interconnects are one of the key technologies which will play a significant role in future developments of CIGS technology. Laser scribing is needed to maintain module efficiency by dividing large scale device to smaller cells interconnected in series. CIGS layer is a thermally sensitive material, and laser modification can induce local structural changes of the active layer and significantly modify the electrical properties. Therefore, the laser modified region can act as series interconnect between the adjacent cells. In this study, we investigated the laser modification of the CIGS active layer with picosecond laser. The EDS analysis revealed the increase of $\mathrm{Cu} /(\mathrm{In}+\mathrm{Ga})$ ratio in laser treated areas while Raman measurements indicated changes in main CIGS peak and formation of the $\mathrm{Cu}$-rich $\mathrm{CuGaSe}_{2}$ phase. Therefore, this resulted in significant electrical conductivity increase in laser-treated areas. Electrical testing of the laser performed P2 micro-welds showed scribe conductivities up to $9.3 \Omega \cdot \mathrm{cm}$ which are acceptable for the cell serial interconnection.
\end{abstract}

DOI: $10.2961 / \mathrm{jlmn} .2016 .02 .0018$

Keywords: interconnects, P2 process, micro-welding, CIGS solar cell, picosecond laser

\section{Introduction}

$\mathrm{Cu}$-chalcopyrite based solar cells such as $\mathrm{Cu}(\mathrm{In}, \mathrm{Ga}) \mathrm{Se}_{2}$ (CIGS) have been established as the most efficient thinfilm technology in converting sunlight into electricity. Moving towards TW scale production will require innovative technological solutions in manufacturing process. Laser scribed monolithic interconnects are one of the key technologies which will play a significant role in future developments of CIGS technology. Laser scribing is needed to maintain module efficiency by dividing large scale device to smaller cells interconnected in series. Usually, three laser scribing processes called P1, P2 and P3 are used for the module processing. P1 is needed for the back contact formation; P2 for the series interconnect formation and P3 for the neighboring cell isolation. Laser patterning is a promising tool for monolithic interconnect formation, although cell deposition processes have to be interrupted for the laser scribing to by applied. These issues are especially important when going to the mass role-to-role production. P2 micro-welding process can be made after the frontcontact layer deposition replacing the standard P2 scribing process which interrupts absorber and window layers deposition $[1,2]$. CIGS layer is thermally sensitive material, and welding process can induce local structural changes, secondary phase formation of the active layer which significantly affects the compound electrical properties. The reports of partial evaporation of selenium with $\mathrm{Cu}$-rich phase formation after laser treatment were reported in the literature $[1,2]$. In this case, the laser modified area can act as series interconnect. Previous investigations showed the advantages of ultrashort pulsed lasers in the CIGS processing due to low thermal effects and localized modification [3-5]. Therefore, the picosecond laser source was selected for the modification experiments.

\section{Experimental}

In this study, we investigated the laser modification of the CIGS active layer for interconnect formation of the adjacent cells (see Fig. 1). The Atlantic series picosecond laser from Ekspla (13 ps, $1000 \mathrm{kHz}, 532 \mathrm{~nm}$ wavelength) was used for the welding experiments. The experimental setup included the laser, beam expander and galvanometer scanner (ScanLab) with an $80 \mathrm{~mm}$ focusing objective for $532 \mathrm{~nm}$ wavelength. The minimum diffraction-limited spot size at the focus position was $10 \mu \mathrm{m}$. The spot size was varied during the experiments by shifting the samples out of the focal position.

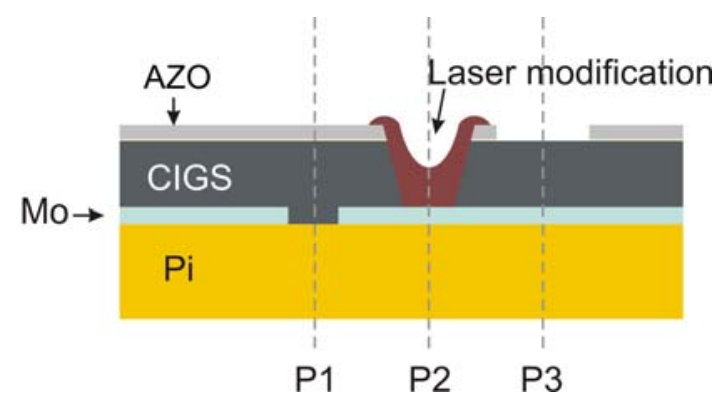

Fig. 1 CIGS cell series interconnection area formed by three-step laser scribing. The conventional P2 laser scribing is replaced by laser welding.

The CIGS solar cell structures with top-contacts were laser treated. Multilayer CIGS solar cell structure from Solarion AG with Al: $\mathrm{ZnO}$ (AZO) top-contact was used in scribing experiments. The cell consisted of sputtered intrinsic $\mathrm{ZnO}$ and chemical-bath-deposited CdS buffer layers, thermal co-evaporated $\mathrm{Cu}(\mathrm{In}, \mathrm{Ga}) \mathrm{Se}_{2}$ absorber layer, sputtered molybdenum back-contact and polyimide (PI) substrate. More details are provided in Fig. 2. 


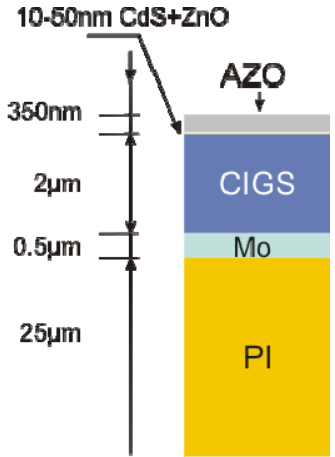

Fig. 2. CIGS solar cell sample used in the P2 laser micro-welding experiments.

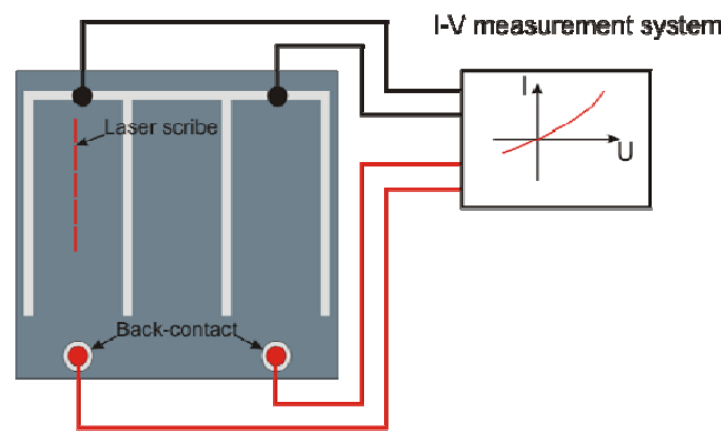

Fig. 3 Electrical measurement setup.

The laser modified area specific conductance was evaluated by applying the linear laser scribing technique (LLST). Laser scribing was applied between the mini-cell contact grid (see Fig. 3). At first the cell parallel conductance was measured before the laser scribing. Then the first laser scribe was applied and the cell conductance was measured again. By repeating the "scribe and measure" procedure several times the relationship between the laser scribe length and cell parallel conductance was obtained. After the measurement, the scribe specific conductance value was extracted by fitting the results with a simple linear function:

$$
G_{P}=\sigma_{S C M} \cdot l,
$$

where $G_{P}$ stands for cell parallel conductance, $\sigma_{S C M}$-scribe conductivity and $l$ represents the scribe length.

Laser affected areas were investigated with SEM (scanning electron microscopy) together with EDS (X-ray energy dispersive spectroscopy) spectrometer. Additional Raman spectroscopy measurements were also applied to investigate structural changes of the laser affected CIGS material.

\section{Results}

\subsection{P2 micro-weld formation}

Picosecond laser treatment of complete solar cell structure to modify the absorber layer was applied. The laser power, pulse overlap and spot size were varied during the tests. The laser processing parameters were selected to modify the CIGS leaving the molybdenum back-contact intact. CIGS P2 micro-welding process depended on different combinations of the laser fluence and pulse overlap. Therefore, the irradiation dose was introduced as a product of these two parameters (fluence $(F)$ multiplied by number of pulses $(N))$. The scribe conductivity was measured for selected laser P2 micro-welding regimes. Typical SEM images of the P2 micro-welds are shown in the Fig. 4.

(a)

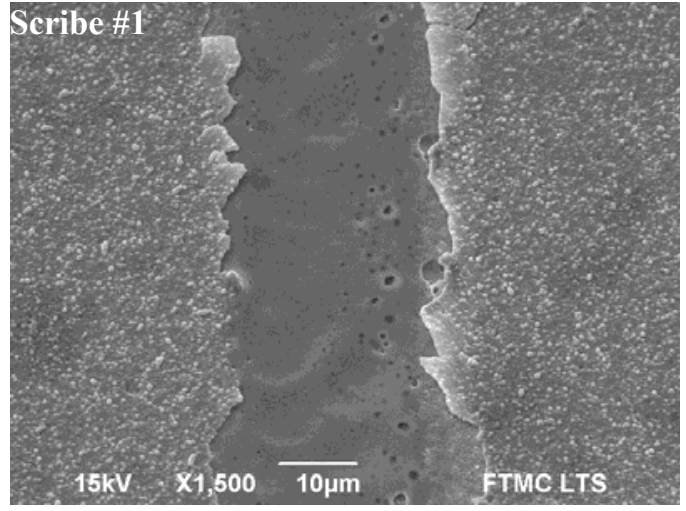

(b)
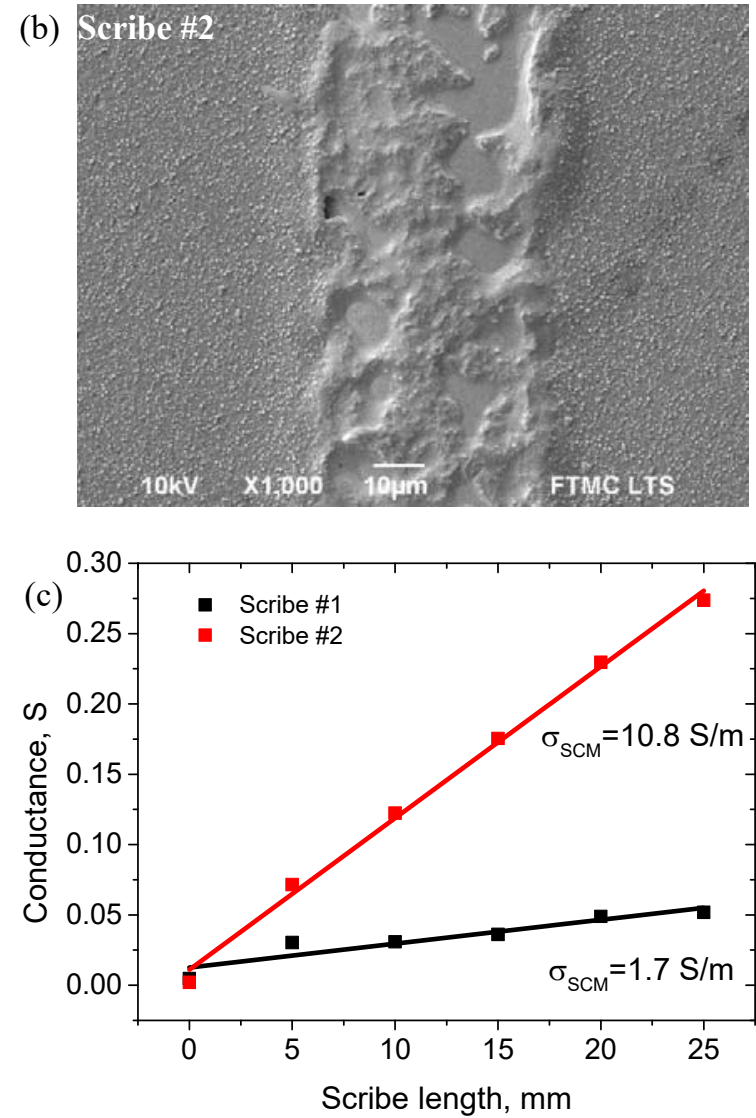

Fig. 4. SEM image of $\mathrm{P} 2$ micro-welds in CIGS structure: (a) scribe \#1, $6.8 \mathrm{~N} \times \mathrm{J} / \mathrm{cm}^{2}, 900 \mathrm{~mm} / \mathrm{s}$; (b) scribe \#2, $43.6 \mathrm{~N} \times \mathrm{J} / \mathrm{cm}^{2}$, $100 \mathrm{~mm} / \mathrm{s}$; (c) scribe conductivity measurement.

Melting together with CIGS layer modification was observed in the P2 welded channel, although the molybdenum back-contact was not damaged during the laser process. In case of laser scribe \#1, the top-contact removal with insignificant CIGS absorber layer modification was observed at laser irradiation dose of $6.8 \mathrm{~N} \times \mathrm{J} / \mathrm{cm}^{2}$. In case of laser scribe \#2, the pulse overlap and laser accumulated irradiation dose was significantly higher $\left(43.6 \mathrm{~N} \times \mathrm{J} / \mathrm{cm}^{2}\right)$ resulting extensive melt formation of the CIGS layer. Also, partial molybdenum back-contact exposure without damage was 
observed. The electrical testing showed $1.7 \mathrm{~S} / \mathrm{m}$ and $10.8 \mathrm{~S} / \mathrm{m}$ scribe conductivity values for laser scribes \#1 and scribe \#2, respectively. Therefore, a significant increase in laser irradiation dose resulted in higher CIGS thermal modification and specific conductance value of the scribe. The typical P2 scribe conductivity reported in the literature is ranging from 15 to $0.1 \Omega \cdot \mathrm{cm}[1,2,6-11]$. Our reported laser scribe \#2 specific conductance was in the range of $10.8 \mathrm{~S} / \mathrm{m}(9.3 \Omega \cdot \mathrm{cm})$, which is acceptable for monolithic interconnection of the adjacent cells.

\subsection{Raman microscopy analysis}

CIGS is a complex multi-component compound, and laser-induced thermal stress can lead to material structural disorders and secondary phase formation near the ablation area. These material structure modifications can result in significant changes of the absorber layer conductivity. Although, shunt formation during the P3 scribing is not desirable $[4,5,12]$, it is rather a positive effect in case of P2 welding. Raman spectroscopy is a useful tool to track material structural changes after the laser modification. Therefore, this technique was introduced to investigate the P2 micro-weld channels. Typical Raman spectra of the CIGS is shown in Fig. 5b. The main peak in the Raman spectra is the $\mathrm{A}_{1}$ vibration line of $\mathrm{CuInSe}_{2}$ at $174 \mathrm{~cm}^{-1}$, with a shift to longer wavenumbers for CIGS [13]. A broad line in the range of $210-230 \mathrm{~cm}^{-1}$ is a combined intrinsic vibration $\mathrm{B}_{2} / \mathrm{E}$ of CIGS [14].

(a)
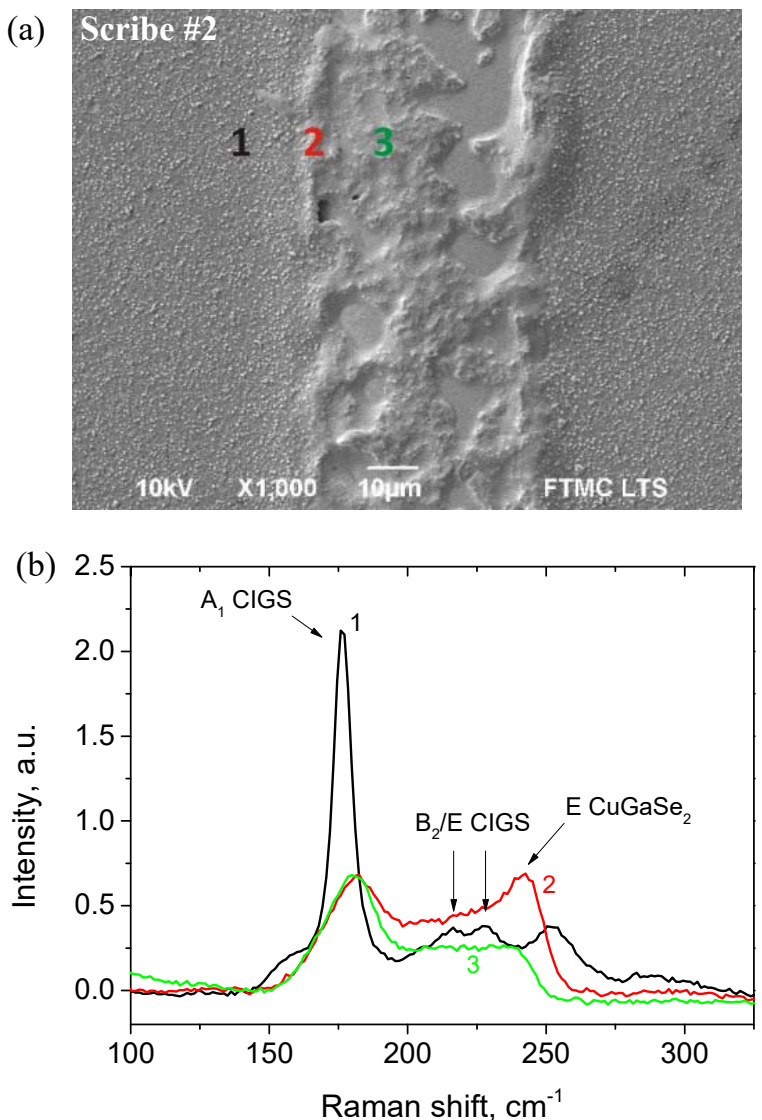

Fig. 5. SEM image of Raman spectroscopy measurement: (a) areas indicated by numbers 1, 2 and 3; (b) Raman spectra of CIGS structure and laser modified P2 micro-weld areas.
After laser processing, the Raman spectra were measured in the areas near to the scribe \#2 micro-weld as shown in the Fig. 5a. The decrease of the main CIGS peak at $174 \mathrm{~cm}^{-1}$ (area 1) with the increasing intensity at $240 \mathrm{~cm}$ ${ }^{1}$ was observed at the edge of P2 channel (area 2). This indicated the generation of $\mathrm{CuGaSe}_{2}$ (CGSe) phase showing a peak at $240 \mathrm{~cm}^{-1}$ in Raman spectra $[15,16]$. Raman measurement at the center of the laser processed scribe (area 3) showed a decrease in main CIGS peak at $174 \mathrm{~cm}^{-1}$, although no CGSe phase formation was observed. Literature reports more than 50 times higher $\mathrm{Cu}$-rich $\mathrm{CuGaSe}_{2}$ phase conductivity compared to CIGS $[17,18]$. Therefore, the formation of CGSe phase at the edge of the laser processed channel could significantly increase the conductivity of $\mathrm{P} 2$ interconnect.

\subsection{EDS analysis}

CIGS and CGSe electrical conductivity can be altered in the range of $10^{6} \Omega \cdot \mathrm{cm}$ and $10^{5} \Omega \cdot \mathrm{cm}$ respectively by adjusting the $\mathrm{Cu} /(\mathrm{In}+\mathrm{Ga})$ element atomic ratios from 0.7 to $1.2 \quad[17-19]$. Therefore, Cu-rich areas where $\mathrm{Cu} /(\mathrm{In}+\mathrm{Ga})>1$ with a significant increase in material conductivity can be detected by tracking of $\mathrm{Cu}$, In and Ga element distributions in laser modified channel area. For this, the EDS spectroscopy analysis of the laser formed P2 micro-weld channels was applied.

(a)

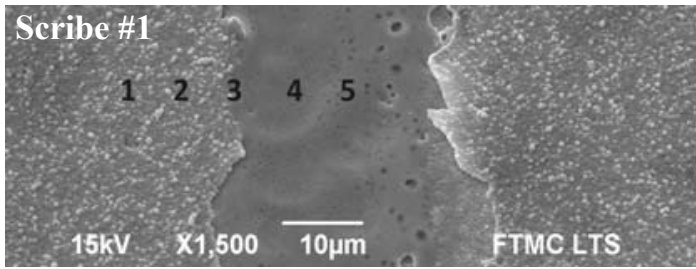

(b) Scribe \#2
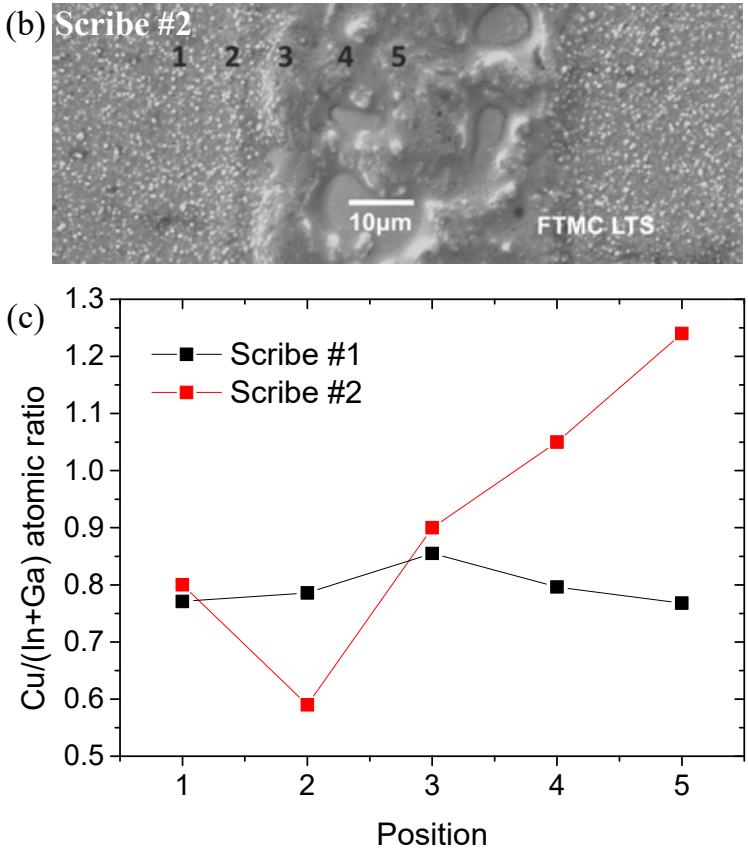

Fig. 6 EDS spectra measurement positions near the P2 microweld: (a) Scribe \#1; (b) Scribe \#2; (c) $\mathrm{Cu} /(\mathrm{In}+\mathrm{Ga})$ ratios in the measured positions.

The average $\mathrm{Cu} /(\mathrm{In}+\mathrm{Ga})$ ratio for laser unaffected CIGS was 0.75 , which is typical for high-performance CIGS de- 
vices. The measurement areas for laser scribe \#1 and scribe \#2 together with $\mathrm{Cu} /(\mathrm{In}+\mathrm{Ga})$ distribution is shown in the Fig. 6 . In the case of the laser scribe $\# 2$, the $\mathrm{Cu} /(\mathrm{In}+\mathrm{Ga})$ ratio tends to increase starting from the edge of the scribe with a maximum value of 1.24 at the center of the channel (see Fig. 6b and c). This indicates the formation of the $\mathrm{Cu}-$ rich phases with different electrical properties. In the case of laser scribe $\# 1$, the $\mathrm{Cu} /(\mathrm{In}+\mathrm{Ga})$ ratios did not exceed 0.85 at any measured position (see Fig. 6a and c). Therefore, no $\mathrm{Cu}$-rich compound is formed in this region resulting lower P2 scribe electrical conductance compared to scribe \#2 (see Fig. 4c). The EDS spectroscopy confirmed the assumption of the CIGS transition to $\mathrm{Cu}$-rich compound after the laser treatment with a significant increase of the material electrical conductance.

\section{Conclusions}

The picosecond laser was found to be suitable for the CIGS layer thermal modification. The laser formed P2 micro-weld channel showed a specific conductivity of $9.3 \Omega \cdot \mathrm{cm}$ which is acceptable for the cell serial interconnection. The picosecond laser irradiation induced CIGS material structural disorder and formed the CGSe phase which was detected by the Raman spectroscopy measurements. The EDS analysis also showed composition changes in laser modified P2 channel. Therefore, the formation of $\mathrm{Cu}$-rich CIGSe and CGSe phases in the laser processed P2 scribe channel resulted in significant increase of the material electrical conductivity.

\section{Acknowledgments}

The research leading to these results was partially funded by the European Union FP7 Programme under grant agreement No. 609355 (APPOLO). We are grateful to Solarion AG, Germany, for technical support and sample preparation.

\section{References}

[1] P. O. Westin, U. Zimmermann and M. Edoff: Sol. Energy Mater. Sol. Cells, 92, (2008) 1230.

[2] P. O. Westin, U. Zimmermann, M. Ruth and M. Edoff: Sol. Energy Mater. Sol. Cells, 95, (2011) 1062.

[3] G. Raciukaitis, S. Grubinskas, P. Gecys and M. Gedvilas: Appl. Phys. A, (2012) 1.

[4] P. Gecys, E. Markauskas, M. Gedvilas, G. Raciukaitis, I. Repins and C. Beall: Sol. Energy, 102, (2014) 82.

[5] P. Gečys, E. Markauskas, J. Dudutis and G. Račiukaitis: Appl. Phys. A, (2013) 1.

[6] S. Pellegrino, D. Scorticati, M. Caldironi and M. Acciarri: Proc. 25th European Photovoltaic Solar Energy Conference and Exhibition, Valencia, Spain, (2010) p. 3654

[7] J. Kessler, S. Wiedeman, L. Russell, J. Fogleboch, S. Skibo, R. Arya and D. Carlson: Proc. Photovoltaic Specialists Conference, Newtown, PA USA, (1996) p. 813.

[8] M. Schüle, C. Schultz, V. Juzumas, K. Stelmaszczyk, M. Weizman, C. Wolf, N. Papathanasiou, B. Rau, R. Schlatmann, V. Quaschning, B. Stegemann and F. Fink: Proc. 28th European Photovoltaic Solar Energy
Conference and Exhibition, Paris, France, (2013) p. 2302

[9] J.-H. Yoon, J.-K. Park, W. M. Kim, J. Lee, H. Pak and J.-h. Jeong: Scientific Reports, 5, (2015) 7690.

[10]J. Ermer, R. Gay, D. Pier and D. Tarrant: J. Vac. Sci. Technol., A, 11, (1993) 1888.

[11]J. Johansson, U. Zimmermann and M. Edoff: Proc. 22nd European Photovoltaic Solar Energy Conference, Milan, Italy, (2007) p. 1922.

[12]P. Gečys and G. Račiukaitis: Eur. Phys. J-Appl. Phys., 51, (2010) 33209.

[13]X. Chuan-Ming, X. Xiao-Liang, X. Jun, Y. Xiao-Jie, Z. Jian, K. Ning, H. Wen-Hao and L. Hong-Tu: Semicond. Sci. Technol., 19, (2004) 1201.

[14]D. Wang, L. Wan, Z. Bai and Y. Cao: Appl. Phys. Lett., 92, (2008) 211912.

[15]C. Rincón and F. J. Ramírez: J. Appl. Phys., 72, (1992) 4321.

[16]M. Li, M. Zheng, T. Zhou, C. Li, L. Ma and W. Shen: Nanoscale Res. Lett., 7, (2012) 675.

[17]S. R. Kodigala, "Electrical Properties of I-III-VI2 Compounds, in Thin Films and Nanostructures", ed. by S.R. Kodigala, (Publisher, Academic Press, Amsterdam 2010). p. 319.

[18]Y.-m. Xue, B.-h. Yang, C.-q. Qu, L. Zhang, C.-m. Xu and Y. Sun: Optoelectron. Lett., 4, (2008) 437.

[19]S. H. Kwon, D. Y. Lee and B. T. Ahn: J. Korean Phys. Soc., 39, (2001) 655.

(Received: June 1, 2015, Accepted: June 29, 2016) 